\title{
Methodology and indications for high-resolution sonography (HRUS) of the nerves
}

\section{Metodologia i zastosowania kliniczne wysokorozdzielczej ultrasonografii nerwów}

JOSEF BÖHM $\mathrm{M}^{\mathrm{E} F}$

Kreiskrankenhaus, Neurologie, Freiberg, Germany

A - Study Design, B - Data Collection, C - Statistical Analysis, D - Data Interpretation, E - Manuscript Preparation, $\mathbf{F}$ - Literature Search, $\mathbf{G}$ - Funds Collection

Summary Imaging-techniques of the peripheral nervous system such as high-resolution ultrasonography (HRUS) and MR-neurography are increasingly utilized worldwide for the investigation of peripheral nerve disorders. Both methods provide important informations about the morphology of the peripheral nerves, nerve-roots and the brachial plexus. The low cost in comparison with MR-neurography, possibility of a dynamic examination, assessing long nerves segments in a short time, bedside-availability, non-invasivity and the possibility of US-guided nerves blocks and therapies make HRUS the ideal imaging tool in peripheral nerve diseases. HRUS allows the detection of alterations even in single fascicles and the perineurium and provides important additional information on morphological aspects and etiology of peripheral nerve pathology. It allows a precise localisation of the nerve lesion and provides information about the underlying etiology. HRUS is especially useful in detecting structural abnormalities of the nerves caused by compression, trauma, tumor, inflammation and a variety of non-neoplastic conditions, including nerve torsion. HRUS can be helpful in operation planning, intraoperative management and in detecting the causes of failed operations. This review presents an overview about the most relevant neurological applications of HRUS taking into account the personal experiences of the author.

Key words: high-resolution ultrasound, peripheral nerve entrapment-syndrome, injuries of the peripheral nerves, tumors of the peripheral nerve sheath, polyneuropathy, nerve torsion.

Streszczenie Techniki obrazowe, jak wysokorozdzielcza ultrasonografia (high-resolution ultrasonography, HRUS) oraz neurografia rezonansu magnetycznego, znajdują coraz szersze zastosowanie w diagnostyce chorób obwodowego układu nerwowego. Obie metody dostarczają istotnych informacji o morfologii nerwów obwodowych, korzeni rdzeniowych oraz splotu barkowego. Zalety HRUS, czyniące z tej metody idealne narzędzie do obrazowania nerwów obwodowych, to: niski koszt (w porównaniu z neurografią rezonansu magnetycznego), dynamiczna ocena morfologiczna, możliwość oceny długich odcinków nerwów w krótkim czasie, możliwość diagnostyki przy łóżku pacjenta, nieinwazyjność oraz możliwość nawigacji przy blokadach i innych zabiegach. W obecnym stopniu zaawansowania technologicznego HRUS pozwala wykryć zmiany nawet w pojedynczych włóknach nerwowych, w onerwiu i w nanerwiu oraz przynosi istotną, dodatkową informację o zmianach morfologicznych i etiologii chorób nerwów obwodowych. HRUS umożliwia ponadto precyzyjną lokalizację uszkodzenia nerwu i dostarcza informacji o jego etiologii. Szczególną przydatność metoda wykazuje w wykrywaniu strukturalnych zmian, powodowanych przez ucisk, jak w zespole cieśni nadgarstka oraz w uszkodzeniu nerwu łokciowego w rowku, przez uraz, guz, zapalenie oraz innego typu uszkodzenia jak skręcenie. Metoda pomocna jest także w diagnostyce różnicowej neuropatii zapalnych. HRUS jest cennym narzędziem także przy planowaniu operacji, w diagnostyce śródoperacyjnej oraz w identyfikowaniu przyczyn niepowodzeń zabiegów. Obecny atykuł zawiera zarys najważniejszych zastosowań HRUS w neurologii, przy uwzględnieniu własnych doświadczeń autora.

Słowa kluczowe: wysokorozdzielcza ultrasonografia, zespół ucisku nerwu, urazowe uszkodzenie nerwu, guz osłonki nerwu obwodowego, polineuropatia, skręcenie nerwu.

Fam Med Prim Care Rev 2015; 17(4): 306-311

\section{Background}

Before imaging methods were introduced 25 years ago, diagnosing peripheral nerve disorders consisted of taking clinical history, a neurological examination and electrophysiological methods. The latter provide information on the type of damage, its severity, progression and possible regeneration of the nerve. However, they cannot provide the morphological image of the nerve and its surroundings, which frequently have clinical significance, especially in the case of mononeuropathy. Because of these factors, highresolution ultrasound (HRUS) constitutes a perfect complement to the aforementioned methods [1]. The conditions for proper neurosonographic diagnostics is the knowledge of the anatomical sections, which are being imaged with an ultrasound, and of the clinical images of peripheral nervous system disorders. In certain cases, the alternative for HRUS can be magnetic resonance neurography [2].

\section{Technical requirements and proper ultrasound imaging of the nerves}

Nerve ultrasonography requires equipment using high frequency, high resolution probes $(12-22 \mathrm{MHz})$, which allow the imaging of most of the superficial nerves. For example, at $15 \mathrm{Mhz}$ frequency the resolution in axial plane reaches up to $250 \mu \mathrm{m}$. This resolution can be increased by increasing 
the frequency of the used probe, until the particular nerve bundles and their sheaths (perineurium and epineurium) are visible. It is impossible to perform imaging of particular axons and endoneurium using this method [3]. Moreover, increasing resolution lowers the depth with which the emitted waves permeate. Thus, structures positioned deeper $(>4 \mathrm{~cm}$ ) cannot be imaged using the highest resolution. In such cases, e.g. during the examination of the sciatic nerve, you need to use a lower resolution probe $(7-10 \mathrm{MHz})$ or use the magnetic resonance neurography method [4]. The quality of the image depends, next to the type of probe used, on the method of image processing. Compound-imaging is employed in order to better distinguish between the tissues and reduce the artifacts. This method generates, based on relevant calculations, a full image from scans made in different angles [3]. Proper image processing programs are now a standard in high-end devices and high class portable devices. Moreover, such devices are equipped with different features for optimizing the image. The quality of the imaging can be additionally improved by placing the probe vertically and by placing the focus on the level of the examined object.

Peripheral nerves are examined with the help of the orientation point method. In this type of examination, you begin with a section search for familiar anatomical structures (bones, vessels, muscles) that should be in the vicinity of the examined nerve. Afterwards you follow the nerve in both distal and proximal directions, in cross and longitudinal sections, which allows to better assess the possible focal
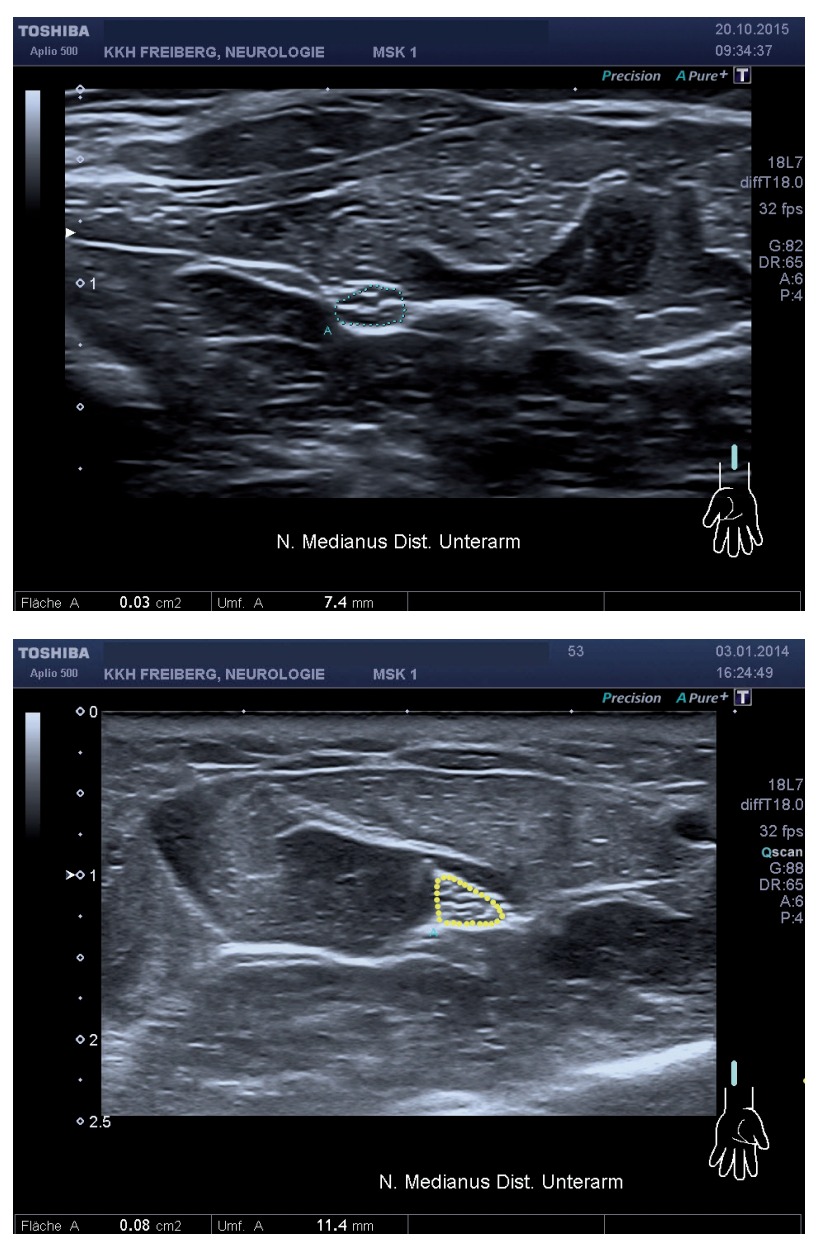

Figure 1. A section of the median nerve in the distal segment of the forearm. Above: regular nerve. Below: nerve with increased section (CSA). The measurement of the section inside the epineurium was performed by circling with a cursor changes in the core diameter, disruptions in continuity or the cause of pressure. Video sequences can prove helpful in examining movement-related damage, e.g. when the ulnar nerve falls out of the cubital tunnel. A cross section of a healthy nerve is similar to a honey comb with hypoechogenic bundles and hyperechogenic sheaths. A longitudinal section is similar to a cable structure. In the distal direction the participation of sheaths and the number of bundles increases. The most significant quantitative parameter assessed in the examination is the cross-sectional area (CSA) [5]. This area is contained in a borderline between hypoechogenic bundles and hyperechogenic epineurium, which is usually clearly visible. During CSA measurement, this line should be circled with the cursor [1]. CSA shows significant compliance both with different measurements taken by the same researcher and with different measurements taken by different researchers [6, 7]. Anatomical points and CSA normative values, including age, sex, height, weight, BMI and other demographic factors significant for orientation are available in relevant sources [8].

\section{Pressure neuropathy}

The common symptom for pressure neuropathies is a decreased nerve diameter at the pressure point, which in cross section manifests by a decrease in CSA and in longitudinal section by a decrease in width. Moreover, as a result of local nerve swelling, an increase in CSA or nerve width can be observed proximally to the compression point (Figs. 1, 2).
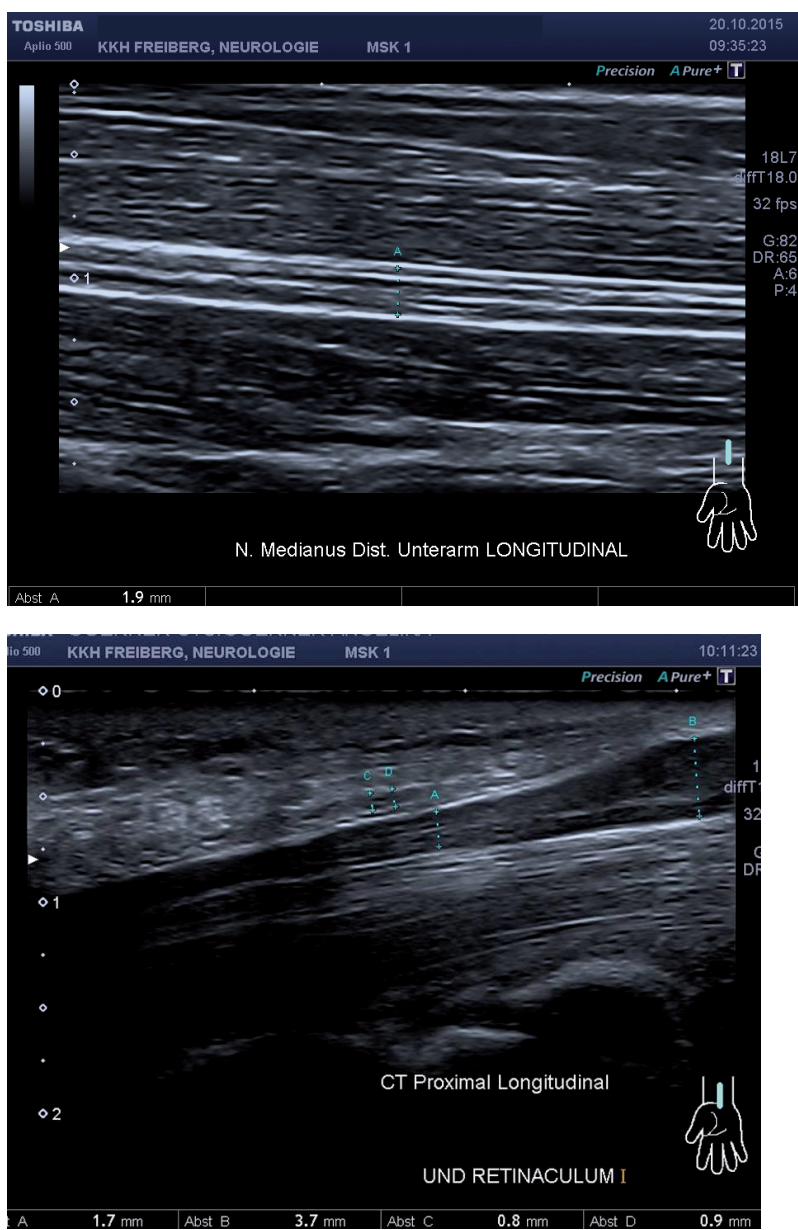

Figure 2. Longitudinal section of the median nerve. Above: regular nerve. Below: nerve of a patient with diagnosed carpal tunnel syndrome with $1.7 \mathrm{~mm}(\mathrm{~A})$ width deficit at the point of compression. Proximally to the compression point (caused by retinaculum marked with letters $C$ and $D, 0.9 \mathrm{~mm}$ diameter) there is local nerve swelling with width increased to $3.7 \mathrm{~mm}$ (B) 
From among all compression syndromes, the carpal tunnel syndrome is the most extensively covered. The syndrome can be diagnosed with a fast and easy ultrasound examination - measuring CSA at point the nerve enters the wrist. According to the recommendations of the American Association of Neuromuscular \& Electrodiagnostic Medicine (AANEM), ultrasonography has the A level recommendation (proven usefulness) in carpal tunnel syndrome diagnostics [9]. If nerve CSA is $\geq 8.5 \mathrm{~mm}$, than diagnostic sensitivity is equal $82 \%$ and specificity is $87 \%$ [10]. With CSA $\geq 10 \mathrm{~mm}^{2}$, these values are $97 \%$ and $89 \%$, respectively [11]. Accord-
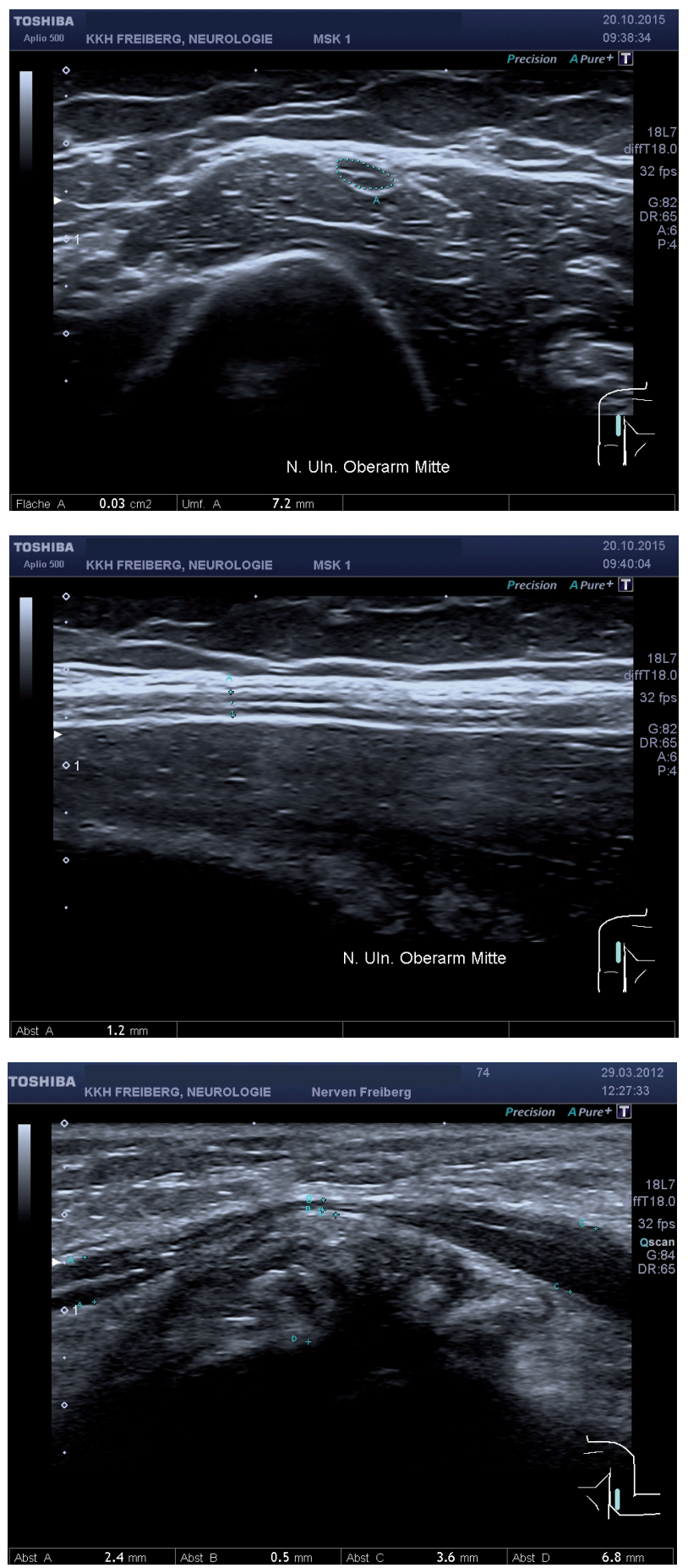

Figure 3. Ulnar nerve. Above: cross section and longitudinal section of a regular nerve. Below: cross section of a nerve with chronic paralysis near the elbow. The nerve trunk is significantly thinned $(B=0.5 \mathrm{~mm}$ ) due to degenerative changes (D), compressing the trunk towards the top. The nerve is significantly swollen distally $(\mathrm{C}=3.6 \mathrm{~mm})$ and proximally $(\mathrm{A}=2.4 \mathrm{~mm})$ from the compression point ing to a meta-analysis of 28 studies and 3.995 hands, with the criterion for carpal tunnel syndrome set at $\geq 9 \mathrm{~mm}^{2}$, the sensitivity was $87 \%$ and specificity $83 \%$ [12]. There are other available measurement methods, described in detail in relevant sources [13]. Despite such high sensitivity and specificity of ultrasonography in carpal tunnel syndrome diagnostics, traditional electrophysiology is indispensable due to its propensity to exclude other peripheral nervous system disorders, assess the severity of nerve damage and assess the results of treatment. An ultrasound can be used as an autonomous method in patients very sensitive to electricity (primarily children) and patients with a defibrillator. An ultrasound is also useful in pre-surgery assessment of the cause of median nerve compression and in detecting anatomic anomalies of the nerve significant for the procedure [3]. Taking into consideration many Level II studies, we can surmise probable (Level B) usefulness of ultrasonography in the identification of these anomalies (ganglions, tenosynovitis, persistent median artery, double median nerve, additional muscles) [9].

In the case of much less common cubital tunnel syndrome (CUTS), there have been, up to date, no recommendations based on facts. The most frequent compression point is located in the upper part of the tunnel, where the nerve flattening occurs, and proximally to that location focal swelling of the nerve in the tunnel occurs [14]. In case of CUTS, we can assess cubital nerve CSA at the point of maximum swelling (set abnormal values: $\geq 10 \mathrm{~mm}^{2}$, sensitivity $88 \%$, specificity $88 \%$ ) [15]. An alternative method is calculating the cubital to humeral ratio (CHR), with abnormal values higher than 1.4. At the same time we have to assess the echogenic structure of the cubital nerve (sensitivity $86 \%$, specificity $87 \%$ ) [16]. Simultaneous use of sonography and electrophysiology in CUTS diagnostics significantly increases the diagnostic accuracy [17]. Similarly as with carpal tunnel syndrome, ultrasound provides additional information on atypical causes of compression, such as post-traumatic bone lesions and soft tissue swelling, and the presence of ganglions and additional muscle, anconeus epitrochlearis. Swollen, hyperechogenic epineurium of the cubital nerve in the tunnel is in all probability created as a result of fibrosis as a reaction to rubbing and can point to recurring instances of the nerve falling out of the tunnel. This suspicion can be confirmed by performing a dynamic examination with the joint in two positions: bent and straight [18].

In CUTS, an ultrasound can sometimes point to compression-like qualities in a different location or an atypically long compression. This occurs in case of a degeneration

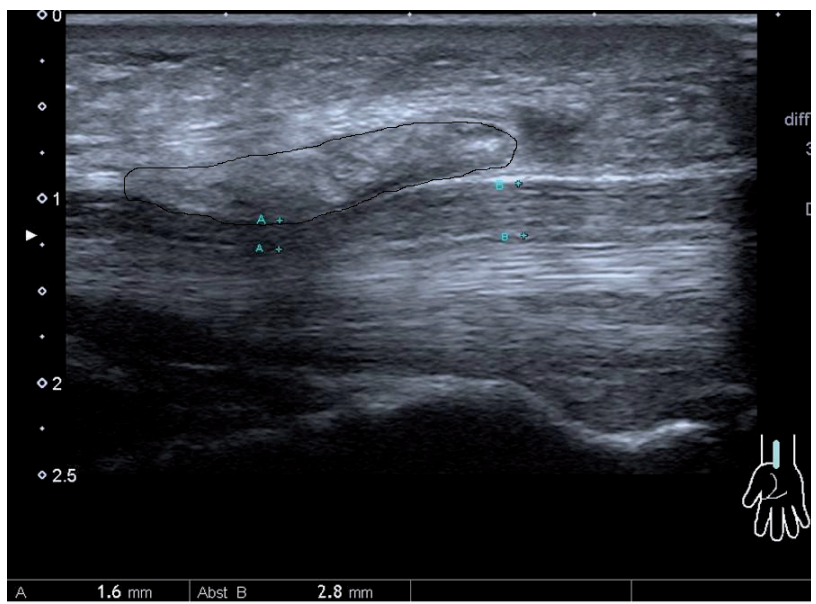

Figure 4. Recurrence of symptoms after surgery for carpal tunnel syndrome. Median nerve is narrowed $(A=1.6 \mathrm{~mm})$ in one segment due to scar tissue that developed above the compression site (marked with a black line) 
near the elbow, created as a result of ulnar bone fracture (late paralysis of the ulnar nerve) [19] (Fig. 3). Also, in case of suspected less common pressure-related syndromes (e.g. Guyon's canal syndrome, supinator muscle syndrome), it is possible, with the help of an ultrasound, to establish alternative causes of compression, such as e.g. ganglion. For diagnostic parameters of different pressure-related syndromes we encourage you to consult the aforementioned source [8].

Ultrasound is becoming increasingly significant in diagnosing afflictions remaining after a decompression surgery for the carpal tunnel syndrome or CUTS. Frequently, it allows to establish the cause of persistent compression, e.g. not fully cut flexor retinaculum, compressed scar tissue, iatrogenic nerve damage with neuroma formation, and also hematoma, synovitis or tumors in the nerve structure (Fig. 4).

\section{Traumatic nerve damage}

If as a result of trauma there are clinical symptoms of complete nerve damage, doubts arise whether the preferred course of treatment is non-surgical, relying on natural reinnervation, or a surgical reconstruction of the nerve is necessary. Electrophysiological examination can provide an indirect answer to this question, but only after several months, by confirming reinnervation has occurred. If reinnervation does not occur within 3 months, we assume severe nerve damage, IV or V degree according to Sunderland [20], an inspection has to be performed and possibly followed by surgical reconstruction [21]. After such period of time, the prognosis for full recovery of function is significantly worse due to an irreversible connective tissue restructuring of the muscles and due to perineural fibrosis [22]. An ultrasound allows early detection, with $93 \%$ accuracy, of severe posttraumatic nerve damage (Sunderland IV and V degree), by showing either a discontinuity or hypoechogenic neuroma, formed on a stump or trunk of the nerve. Thus, an ultrasound hastens the decision to undertake possible surgical intervention [23]. HRUS localizes the point in which discontinuity occurred or where a neuroma formed with up to millimeter accuracy (Fig. 5). Moreover, it allows the detection of multipoint nerve damage and not infrequently the etiology of the damage (e.g. compression caused by a hematoma, connective tissue or ossification processes) [24].

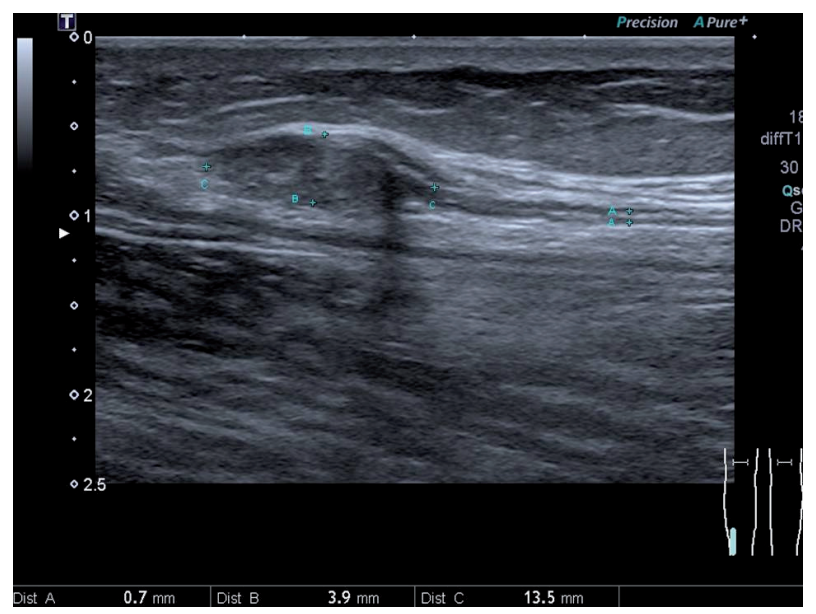

Figure 5. Sural nerve damage after a cut injury, $V$ degree according to Sunderland. Stump neuroma (3.9 $\times 13.5 \mathrm{~mm}$; B and C) is visible at the end of the healthy nerve (A $0.7 \mathrm{~mm}$ )

Moreover, an ultrasound can be used for pre-surgery mapping [25] and intra-surgery, for precise identification of healthy and damaged nerve bundles [26].

\section{Peripheral nerve sheath tumors}

These tumors most frequently occur near core roots, brachial plexus and on large nerve trunks [24]. Histologically, most often we deal with a neurionoma (schwannoma) or a neurofibroma. Both types are characterized with a slow growth that can span several years or several decades. Thus, the neurological deficits take a long time to manifest. Thanks to proper microsurgical technique you can remove the tumors, especially neurionomas, without risk of leaving a neurological deficit [24]. A classic sonographic symptom of a solid sheath tumor is the image of entry or emergence point of the nerve into or from the tumor, which is spindle-shaped, oval, round or irregular (Fig. 6). Smaller tumors are less vascularized and yield a homogenous and hypoechogenic image. As the tumor grows larger and older, it becomes more vascularized and retroactive changes in the tumor matrix, such as cysts or areas with heightened or nonuniform echogenicity, appear [24]. An ultrasound does not allow to completely differentiate between different types of tumors [27]. Despite that, diagnosing the tumor proves valuable, as nerve sheath tumors are very rarely diagnosed based on a physical examination alone. This finding is a conclusion of a study in which out of 88 benign sheath tumors, only $8 \%$ were properly diagnosed in the pre-surgical period and without the use of neurosonography or magnetic resonance neurography [28]. For information on other, rare but frequently malignant, processes taking place in soft tissues we encourage you to consult the relevant source [29].

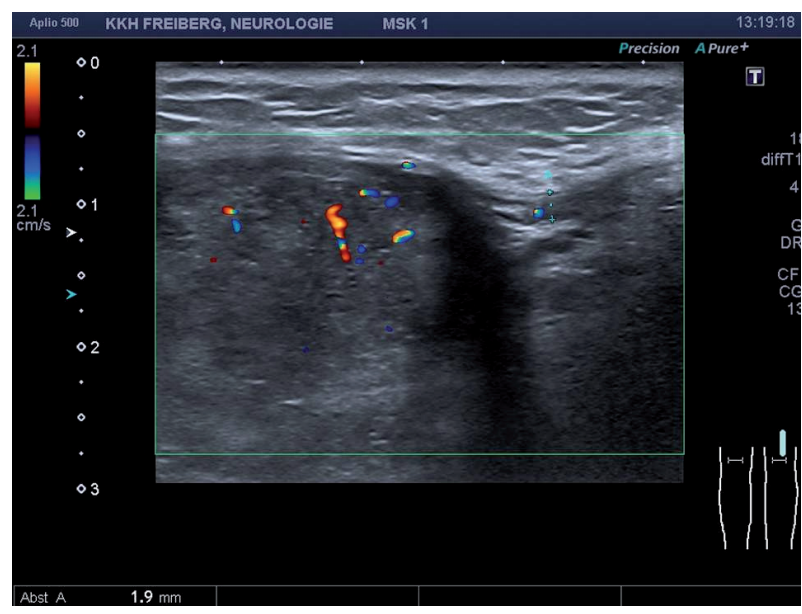

Figure 6. Peroneal nerve sheath schwannoma located near the head of the fibula. Limited vascularization is visible on the left of the figure. Proximal ingress of the nerve $(1.9 \mathrm{~mm}$ diameter) into a hypoechogenic, poorly vascularized tumor is visible on the right

\section{Polyneuropathies}

In case of polyneuropathies an ultrasound shows either a general or a multifocal enlargement of CSA, possibly limited to particular nerve bundles, which can be seen in the cross section. Moreover, an increase of the thickness of the nerve can be visible in the longitudinal section (Fig. 7). These changes are described mainly for upper extremities, in the proximal segments of the nerves (cervical spinal nerve roots, brachial plexus and proximal segment of the shoulder). Etiologically, these changes are present mostly in demyelinating polyneuropathies with either autoimmune (AIDP, CIDP, MMN, MADSAM) or hereditary (CMT1a, HNPP) causes [30]. The listed locations are frequently difficult to subject to electrophysiological diagnostics. According to own experiences, nerve trunk hypertrophy visible on an ultrasound 
helps to differentiate between autoimmune neuropathy (multifocal motor neuropathy, MMN) and sclerosis multipla.

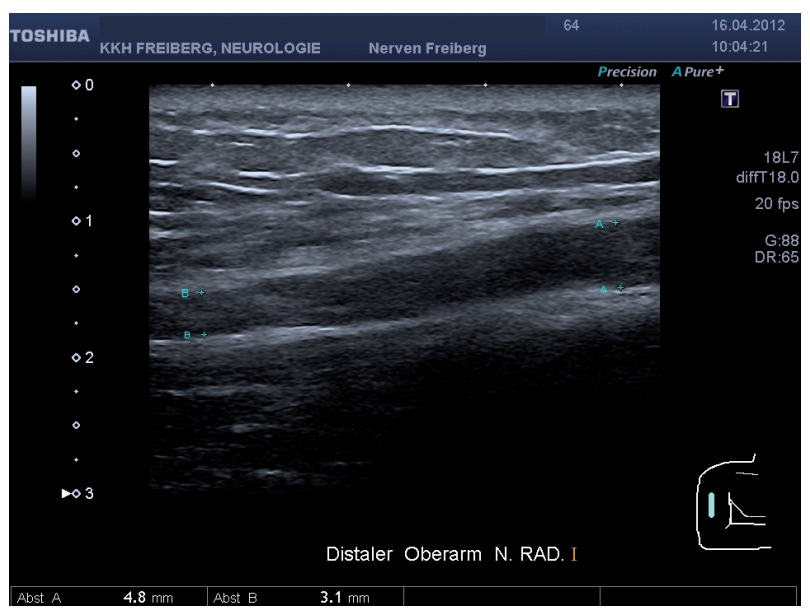

Figure 7. Multifocal motor neuropathy. Longitudinal section of radial nerve with in the distal segment of the shoulder with general enlargement and fluctuation of the diameter (proximally $A=4.8 \mathrm{~mm}$, distally $B=3.1 \mathrm{~mm}$ )

\section{Torsional nerve injury}

For a long time torsional nerve injury was described in cases of injuries to the posterior interosseous median nerve branch and anterior interosseous radial nerve branch. This kind of injury can also occur in cases of such nerves as: nervus radialis communis, suprascapular nerve, axillary nerve, and musculocutaneous nerve. Torsional nerve injury can either be a single occurrence or multiple injuries can occur subsequently. They can affect the entire nerve trunk or just particular bundles [31].

Typical clinical symptoms are similar to those pointing towards neuralgic shoulder amyotrophy. Initially, shooting pains appear in the damaged segment of the nerve. The pain is followed by the occurrence of, in different time periods, motor deficit in the muscles supplied by the damaged nerve. It is argued that the probable cause of this injury is a local inflammation in segments subjected to frequent torsional movements [32]. Recently, a group of 14 patients with neuralgic shoulder amyotrophy was described. Seven out of these 14 patients were diagnosed with torsional injury with the help of sonography. The diagnosis was later confirmed during surgery. In $85 \%$ of these patients the torsional injuries were located in the radial nerve. It is believed that first compression occurs and later develops into torsional injury. Nerves which are frequently subjected to torsional movements are more prone to develop torsional injuries resulting from compression, which can cause an atrophy of elastic elements that return the nerve into proper shape when the joint is in resting position [32]. A typical sonographic image of a torsional injury includes nerve thinning, which is similar to a wristwatch glass with swelling, more frequently marked proximally, rather than distally [24] (Fig. 8). Due to the fact that an early surgical intervention (detorsion or resection with transplanted nerve anastomosis) significantly improves the prognosis [24], an ultrasound examination should be performed in each case of unclear, painful mononeuropathy and neuralgic shoulder amyotrophy not showing any signs of spontaneous remission.

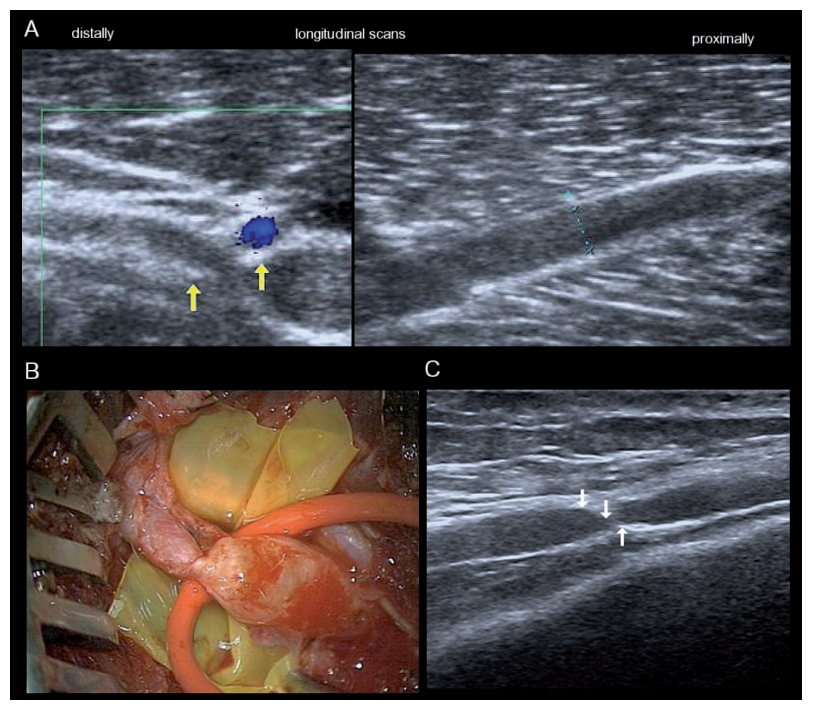

Figure 8. Torsional injury of the radial nerve. A: the arrows show a contraction of the nerve similar to wristwatch glass with proximal nerve enlargement. B: Inter-surgery confirmation of torsional injury. C: Another torsional nerve injury several months later, distally from the location of the first injury. Source: [24] kindly provided by Springer Publishing

\section{Practical conclusions}

- As a complementary method to electrophysiology, nerve ultrasound improves diagnostic accuracy and becomes more and more a routine method in the diagnostics of peripheral nervous system disorders.

- In the case of compression syndromes, ultrasound allows to locate the compression point, establish the cause and detect any possible anatomical anomalies relevant for a planned surgery.

- An ultrasound frequently allows to detect the cause for the return of symptoms post-surgery.

- An ultrasound allows early detection of severe post-traumatic nerve damage that qualifies for immediate surgery.

- An ultrasound allows to locate, establish the scope and cause of post-traumatic peripheral nerve damage.

- An imaging of peripheral nerve sheath tumors and their vascularization can be performed.

- An ultrasound allows to perform imaging of different types of pathology, inter alia torsional nerve injury which is a potential complication of neuralgic shoulder amyotrophy. This allows to commence treatment early.

German (original)-to-Polish translation - Jakub Antczak.

Polish-to-English translation - Lemon Translation Agency, Wrocław.

Source of funding: This work was funded by the author's resources.

Conflict of interest: The author declares no conflict of interests.

\section{References}

1. Fornage BD. Peripheral nerves of the extremities: imaging with US. Radiology 1988; 167: 179-182.

2. Titelbaum DS, Frazier JL, Grossman RI, et al. Wallerian degeneration and inflammation in rat peripheral nerve detected by in vivo MR imaging. AJNR Am J Neuroradiol 1989; 10: 741-746. 
3. Böhm J, Schelle T. Stellenwert der hochauflösenden Sonografie bei der Diagnostik peripherer Nervenerkrankungen. High resolution ultrasound in the diagnosis of peripheral nerve disorders. Akt Neurol 2013; 40: 258-268.

4. Wessig C, Bendszus M, Reiners K, et al. Läsionen peripherer Nerven: MR-neurografie als innovative Ergänzung zur Elektrodiagnostik. Klin Neurophysiol 2011; 42: 231-238.

5. Kopf H, Loizides A, Mostbeck GH, et al. Diagnostische Sonografie peripherer Nerven: Indikationen, Techniken und Pathologien. Ultraschall in Med 2011; 32: 242-266.

6. Tagliafico A, Martinoli C. Reliability of side-to-side sonographic cross-sectional area measurements of upper extremity nerves in healthy volunteers. J Ultrasound Med 2013; 32: 457-462.

7. Boehm J, Scheidl E, Bereczki D, et al. High-resolution ultrasonography of peripheral nerves: measurements on 14 nerve segments in 56 healthy subjects and reliability assessments. Ultraschall Med 2014; 35: 459-467.

8. Schelle T. Methodik und was kann die Nervensonografie. Klin Neurophysiol 2015; 46: 79-89.

9. Cartwright M, Hobson-Webb L, Boon A, et al. Evidence-based guideline: neuromuscular ultrasound for the diagnosis of carpal tunnel syndrome. Muscle Nerve 2012; 46: 287-293

10. Mohammadi A, Afshar A, Etemadi A, et al. Diagnostic value of cross-sectional area of median nerve in grading severity of carpal tunnel syndrome. Arch Iran Med 2010; 13: 516-521.

11. Ziswiler HR, Reichenbach S, Vogelin, et al. Diagnostic value of sonography in patients with suspected carpal tunnel syndrome: a prospective study. Arthritis Rheum 2005; 52: 304-311.

12. Tai TW, Wu CY, Su FC, et al. Ultrasonography for diagnosing carpal tunnel syndrome: a meta-analysis of diagnostic test accuracy Ultrasound Med Biol 2012; 38: 1121-1128.

13. Peer S, Gruber H, Loizides A. Sonography of carpal tunnel syndrome: why, when and how. Imaging Med 2012; 4: $287-297$.

14. Assmus H, Antoniadis G, Bischoff C. Karpaltunnel-, Kubitaltunnel- und seltene Nervenkompressionssyndrome. Dtsch Arztebl Int 2015; 112: 14-26.

15. Volpe A, Rossato G, Bottanelli M, et al. Ultrasound evaluation of ulnar neuropathy at the elbow: correlation with electrophysiological studies. Rheumatology 2009; 48: 1098-1101.

16. Gruber H, Glodny B, Peer S. The validity of ultrasonographic assessment in cubital tunnel syndrome: the value of a cubital-tohumeral nerve area ratio (CHR) combined with morphologic features. Ultrasound Med Biol 2010; 36: 376-382.

17. Beekman R, Van Der Plas JP, Uitdehaag BM, et al. Clinical, electrodiagnostic, and sonographic studies in ulnar neuropathy at the elbow. Muscle Nerve 2004; 30: 202-208.

18. Plaikner M, Loizides A, Loescher W, et al. Thickened hyperechoic outer epineurium, a sonographic sign suggesting snapping ulnar nerve syndrome? Ultraschall Med 2013; 34: 58-63.

19. Shimizu H, Beppu M, Arai T, et al. Ultrasonographic findings in cubital tunnel syndrome caused by a cubitus varus deformity. Hand Surg 2011; 16: 233-238.

20. Sunderland S. The anatomy and physiology of nerve injury. Muscle Nerve 1990; 13: 771-784.

21. Kretschmer T, Assmus H, Antoniadis G. Nervenchirurgie: Trauma - Tumor - Kompression. Berlin Heidelberg: Springer-Verlag; 2015.

22. Burnett MG, Zager EL. Pathophysiology of peripheral nerve injury: a brief review. Neurosurg Focus 2004; 16 : E1.

23. Zhu J, Liu F, Li D, et al. Preliminary study of the types of traumatic peripheral nerve injuries by ultrasound. Eur Radiol 2011; 21: 1097-1101.

24. Penkert G, Böhm J, Schelle T. Focal peripheral neuropathies. Imaging, neurological, and neurosurgical approaches. Berlin Heidelberg: Springer-Verlag; 2014.

25. Gofeld M, Bristow SJ, Chiu S, et al. Preoperative ultrasound-guided mapping of peripheral nerves. J Neurosurg 2013; 119: 709-713.

26. Koenig RW, Schmidt TE, Heinen CP, et al. Intraoperative high-resolution ultrasound: a new technique in the management of peripheral nerve disorders. J Neurosurg 2011; 114: 514-521.

27. Tsai WC, Chiou HJ, Chou YH, et al. Differentiation between schwannomas and neurofibromas in the extremities and superficial body: the role of high-resolution and color Doppler ultrasonography. J Ultrasound Med 2008; 27: 161-166.

28. Kehoe NJ, Reid RP, Semple JC. Solitary benign peripheral-nerve tumours. Review of 32 years' experience. J Bone Joint Surg Br 1995; 77: 497-500.

29. Gruber H, Glodny B, Bendix N, et al. High-resolution ultrasound of peripheral neurogenic tumors. Eur Radiol 2007; 17: 2880-2888.

30. Scheidl E, Böhm J, Simó M, et al. Different patterns of nerve enlargement in polyneuropathy-subtypes as detected by ultrasonography. Ultrasound Med Biol 2014; 40: 1138-1145.

31. Guerra WK, Schroeder HW. Peripheral nerve palsy by torsional nerve injury. Neurosurg 2011; 66: 1018-1024.

32. Lundborg G. Commentary: hourglass-like fascicular nerve compressions. J Hand Surg Am 2003; 28: 212-214.

Address for correspondence:

Dr. Josef Böhm

Dr. Külzstr. 10

09599 Freiberg

Germany

Tel.: +49 3731-218984

E-mail: josefboehm@arcor.de

Received: 06.10.2015

Revised: 19.10.2015

Accepted: 25.10.2015 